\title{
A Survey of literature on Shuttle Based Storage and Retrieval Systems
}

\author{
Nenad Ž. Kosanić \\ Associate Professo \\ University of Belgrade \\ Faculty of Mechanical Engineering \\ Goran Z. Milojević \\ Teaching assistant \\ University of Belgrade \\ Faculty of Mechanical Engineering
}

Nenad Đ. Zrnić

Full Professor University of Belgrade Faculty of Mechanical Engineering
The last decade brought the blooming of the shuttle-based automated storage and retrieval system (SBS/RS) in many industrial applications. They proved the superiority over the mini-load automated storage and retrieval system mainly due to higher throughput capacity, high flexibility of future extension, much better energy efficiency resulting from lower energy consumption and high energy regeneration capability. A comprehensive literature review on $S B S / R S$ given in the paper pointed out main specifics and crucial approximations and assumptions of the developed system performance estimation models or control strategies, as well as the main conclusions resulting from the obtained results. Presented modeling approaches could be a valuable tool for $S B S / R S$ designers and other related decision makers to estimate the system efficiency in the starting phase of SBS/RS design activities.

Keywords: Shuttle based storage and retrieval systems, Elevator lifting table cycle time, Shuttle vehicle cycle time, Throughput performance, $S B S / R S$ energy consuption, SBS/RS energy regeneration.

\section{INTRODUCTION}

In the last decade SBS/RS have become preferable solution for the automated handling of totes, cartons and bins in many industrial applications. System consists of multiple aisles of storage racking with single or multiple depths, shuttle vehicles servicing the racking tiers and the elevator per every aisle providing the vertical transport among racking tiers, Figure 1.

Elevator preferably has two lifting tables operating independently of each other, Figure 2. At a beginning of each tier there are buffer positions for the incoming and outcoming totes where they wait to be loaded by the elevator lifting table or shuttle vehicle. System has two possible configurations: Tier-captive where every tier has dedicated shuttle vehicle, and tier-to-tier configuration where number of tiers exceeds the number of shuttles. In this case the special elevator at the back of the racking moves the shuttle vehicles between tiers. The tote maximal weight is usually $50 \mathrm{~kg}$ and its dimensions are in the range between $150 \times 200 \times 80 \mathrm{~mm}$ and $600 \times 400 \times 250$ $\mathrm{mm}$. The SBS/RS has many advantages over the miniload automated storage and retrieval system spatially higher throughput capacity, higher flexibility of future extension and much better energy efficiency resulting from lower energy consumption and high energy regeneration capability. But the main power of the system still remains in possibility to support order picking systems with extremely high requested picking rates which became a decisive and ultimate market need.

On the other hand SBS/RS could require high investment cost so the careful design is needed.

Received: March 2018, Accepted: April 2018

Correspondence to: Dr Nenad Kosanić, Assoc.Professor

Faculty of Mechanical Engineering,

Kraljice Marije 16, 11120 Belgrade 35, Serbia

E-mail: nkosanic@mas.bg.ac.rs

doi:10.5937/fmet1803400K

(C) Faculty of Mechanical Engineering, Belgrade. All rights reserved
The models given into SBS/RS literature review could help the designers and other related decision makers to estimate the system efficiency in the starting phase of SBS/RS design activities and assure proper operation of the system by preventing node point congestions or poor system utilization.

\section{LITERATURE REVIEW}

The analytical model for the tier-captive SBS/RS transaction cycle time estimation including transaction waiting time is presented in [1]. Component of the cycle time related to the elevator and shuttle vehicle movement is obtained as a weighted average of all possible movements. Acceleration and deceleration of shuttle vehicles and elevator are took into consideration. Retrieval transaction waiting time is obtained by modeling one tier by open queuing network using five sequential steps of the decomposition method. Simulation study is introduced to validate analytically obtained main system performances, transaction cycle time, elevator and shuttle vehicle utilization, elevator and shuttle vehicle waiting times considering different system configurations. Proposed model provides main system performance evaluation in a very short period of time which is extremely important in system design conceptualization phase.

Simulation model for the tier-captive SBS/RS elevator lifting table and shuttle vehicle cycle time evaluation and resulting system throughput performance calculation is given in [2]. Two velocity type profiles depending on whether the achieved peak velocity is less or equal to maximum velocity are used in elevator lifting table and shuttle vehicle cycle time estimation. Single (SCC) and dual command cycle (DCC) times are considered. System throughput capacity is in the majority of configurations restricted by the elevator throughput capacity although the shuttle vehicles could handle mush bigger number of totes. So authors recom- 


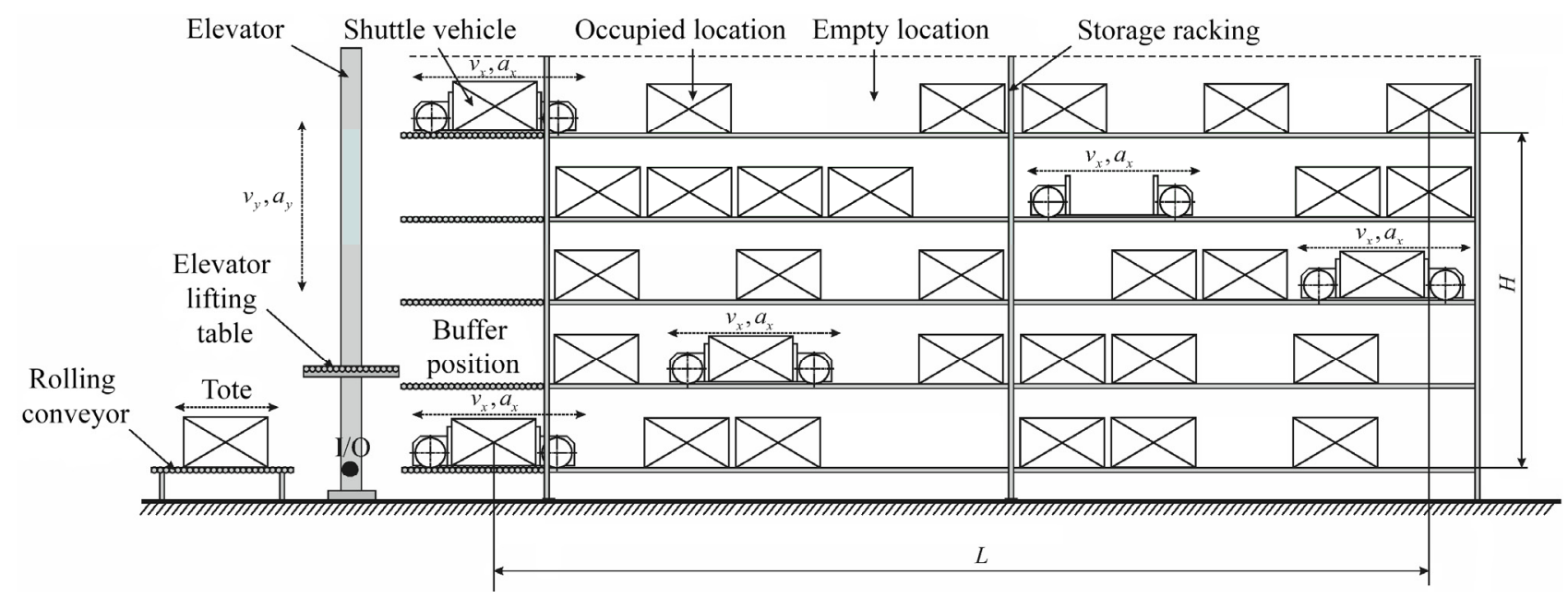

Figure 1. Tier-captive SBS/RS configuration - side view

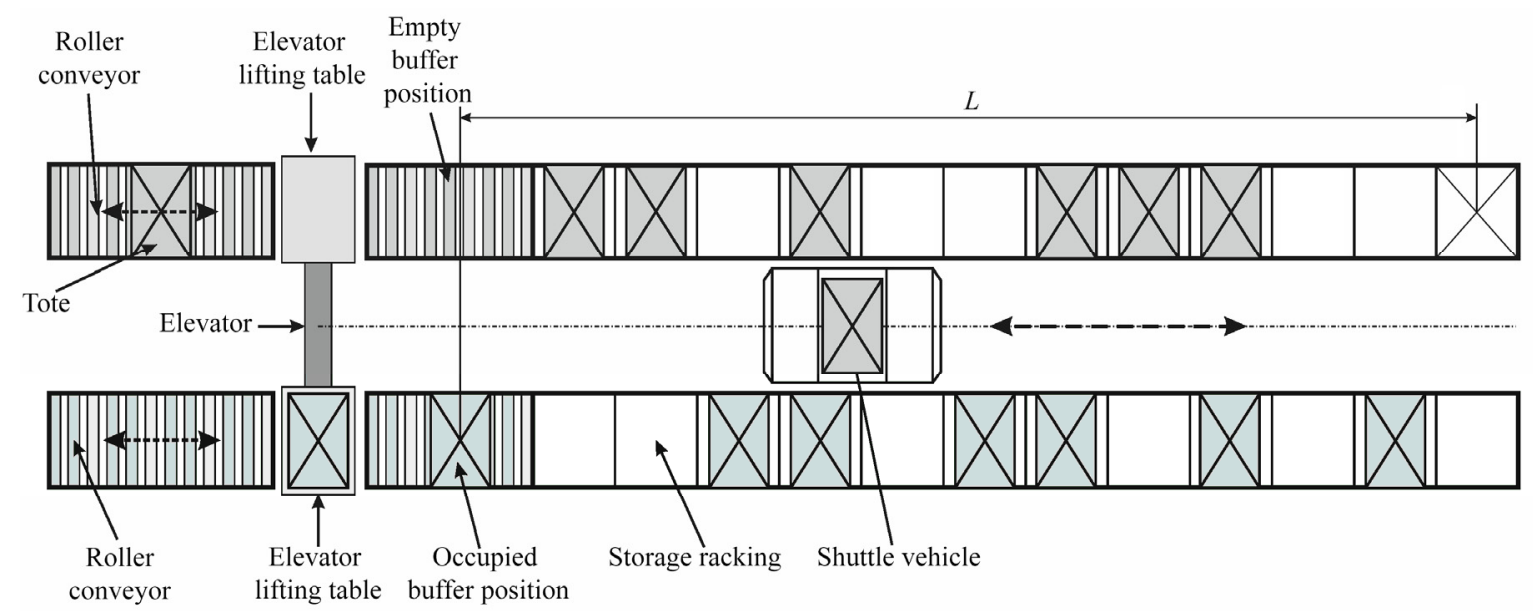

Figure 2. Tier-captive SBS/RS configuration - top view

mended that tier-captive assumption could be released by allowing the system to work with less number of shuttle vehicles that racking tiers. In that case the spatial elevator for the shuttle vehicles vertical movement between tiers is needed. One of the crucial warnings given in paper is that checking of the elevator bottleneck should become mandatory in the system design strategy.

The simulation model for the estimation of the influence of tier-captive SBS/RS main design variables onto the system costs and main performance, average retrieval transaction cycle time including the waiting time, average elevator and shuttle vehicle movement time (as a part of the cycle time) and average shuttle vehicle and elevator utilization is presented in [3]. The proposed framework should significantly decrease the time needed for the early phase of SBS/RS design activities and assure proper operation of the system. Model includes annualized costs of the space, racking and elevators and shuttle vehicles. In the calculation of the elevator and shuttle vehicle expected cycles time it is assumed that average travel distance is a half of the maximal travel distance and acceleration and deceleration are treated as a fixed time components. Case study with 64 racking configurations is performed. The results indicated that smaller number of aisles led to cost minimization and maximization of the aisle length led to minimization of number of required shuttle vehicles. Also for the elevator or shuttle vehicle utilization below 0.9 the influence of the waiting time on average cycle time is very small but further utilization increase would dramatically harm system performances. In order to increase the system throughput tier number has to be adjusted according to the maximal utilization of the shuttle vehicles and number of aisles has to be adjusted according to the maximal utilization of the elevator. According to the authors conclusion optimal system configuration needs to have a smaller number of longer aisles.

Analytical approximated model for the tier-captive SBS/RS elevator lifting table and shuttle vehicle cycle time estimation is presented in [4]. Model is based on probability theory and FEM guidelines given in [5]. Analytical model for the estimation of the energy regeneration during braking of the shuttle vehicle and elevator lifting table and corresponding mass of $\mathrm{CO}_{2}$ emission saved from going into the atmosphere is also given. Equivalent amount of forest saved by the energy regeneration also could be estimated. Eleven racking configurations serviced by eleven elevator lifting table and shuttle vehicles velocity profiles are investigated. The elevator proved its biggest possibility to become the system bottleneck. The author pointed out the great importance of introducing of energy regeneration concept into future development and planning of the SBS/RS. 
An analytical approximated model for the tiercaptive SBS/RS elevator lifting table and shuttle vehicle SCC and DCC time estimation is presented in [6]. Depending on four acceleration and deceleration rates, very high, if maximal speed can be achieved in less than half of unitary displacement, if maximal speed can be achieved in more than half of unitary displacement and in case of very low rates when it is not possible to get the maximal speed, four corresponding analytical models are developed. The models calculate the expected travel time as the weighted average of all possible travel times. Procedure requests exact calculation of established summations but not all summations are always computable so some of them have to be approximated. Analytically obtained results are validated through random and exact travel simulations approach. Minor discrepancies are reported.

In the [7] one aisle of the tier-captive SBS/RS is modeled by $M|G| 1 \mid$ queuing model in order to estimate main system performances. The elevator and shuttle vehicle cycle times are approximated. Storage transactions inter-arrival time is estimated as approximated expected elevator SCC time and storage transaction service time is estimated as shuttle vehicle DCC time divided with a number of tiers. Retrieval transactions inter-arrival time is estimated as expected shuttle vehicle DCC time divided with a number of tiers and retrieval transaction service time is estimated as elevator SCC time. The cycle time for the whole system is adopted as longer time between shuttle vehicle DCC time divided with a number of tiers and elevator SCC time with added waiting time estimated by queuing model. Different racking lengths and heights configurations with elevator and shuttle vehicle performing different combinations of cycle types are investigated. Analytically obtained results are validated by simulation model.

Analytical model for tier-captive SBS/RS throughput performance capacity evaluation is presented in [8]. Two velocity type profiles are adopted. SCC times for the elevator lifting table and shuttle vehicle are calculated according to cumulative distribution function of the elevator lifting table and shuttle movement among input/output location and any randomly selected tier (for the elevator lifting table) or any randomly selected storage location in the tier (for the shuttle vehicle). For the DCC times calculation one more cumulative distribution function of the elevator lifting table and shuttle movement among any two randomly selected tier (for the elevator lifting table) or any two randomly selected storage location in the tier (for the shuttle vehicle) is took into consideration. Also approximated analytical model for the elevator lifting table and shuttle vehicle SCC and DCC times based on the probability theory and FEM guidelines is presented. Results obtained by two presented models are compared and validated by simulation. Five velocity profiles and nine different racking configurations are investigated. Results indicated that approximated model strongly overestimated elevator lifting table DCC time but provided very good estimation for the shuttle vehicle cycle time. Also results obtained with analytical model are in very good correlation with results provided with simulation model. Proposed analytical strategy could be a valuable tool for the main system performance estimation in the early stage of the system design.

Simulation model for tier-captive SBS/RS performances estimation through elevator lifting table and shuttle vehicle DCC time calculation is presented in [9]. Two velocity type profiles are taken into consideration. Two velocity profiles and nine different racking configurations are investigated. Results proved strong system sensitivity to the elevator throughput capacity. For the same system capacity better results could be obtained for the lower racking configurations and bigger number of aisles. The tier-to-tier configuration could be considered in the case of higher racking configurations. For the bigger number of racking columns the shuttle vehicle velocity profile should be also high.

The tier-captive SBS/RS optimal racking geometry resulting in system performance maximization is investigated in [10]. System throughput is obtained by modeling the one racking tier by an open $\mathrm{M} / \mathrm{M} / 1 / \mathrm{K}$ queuing model. The elevator SCC time multiply with number of tiers is estimated as the inter-arrival time. The service time is estimated as expected shuttle vehicle DCC times. Expected elevator and shuttle vehicle cycle times are approximated. Modeling strategy reviled that higher racking are not affected by the length dimension throughput-wise. Also throughput capacity is not so sensitive to the racking depth in the case of higher racking. Simulation model is applied for the verification of the analytically obtained results. Good results correlation is reported. The main issue of the paper is very interested idea that optimal racking geometry could be achieved using the linear optimization of the throughput expression from the applied $\mathrm{M} / \mathrm{M} / \mathrm{1} / \mathrm{K}$ queuing model. Experiments showed that system throughput increase resulting from the depth increase, stopped after triple racking depth. Also with racking depth increase the racking height decreases but only to triple-deep racking configuration. Racking depth increase results also in racking length and system required space decrease.

Analytical model for the tier-captive double-deep $\mathrm{SBS} / \mathrm{RS}$ throughput performance estimation is presented in [11]. Depending on two storage fill-grade factors ranges using the probability theory elevator lifting table and shuttle vehicle SCC and DCC time expressions are derived. Two velocity type profiles are taken into consideration. Process of the rearrangement of the blocking tote to the nearest free unoccupied location witch could occur during the retrieval process is also carefully modeled. In presented case study simulation model is applied for the verification of the analytically obtained results. One racking configuration and three different elevator lifting table and shuttle vehicle velocity profiles are taken into consideration. First shuttle vehicle DCC times and corresponding throughput performances with three velocity profiles and ten fill-grade factor values are investigated. Then elevator lifting table SCC and DCC times and corresponding throughput performances for three different operating modes are estimated. Finally complete SBS/RS throughput capacity is evaluated. For the bigger values of the fill-grade factor the shuttle 
vehicle DCC time increase is reported mainly due to the frequent needed tote rearrangements and increased rearrangement distances. Study confirmed the elevator as a usual system bottleneck resulting in small vehicle utilization. To increase the shuttle vehicle utilization the tier-captive assumption should be released. The presented modeling strategy offers a great help in the system efficiency assessment during the early stage of the system planning.

A comprehensive literature review on the SBS/RS is given in [12].

Analytical approach for the tier-captive SBS/RS throughput estimation based on modeling one tier by $\mathrm{M}|\mathrm{M}| 1 \mid \mathrm{K}$ and more exact $\mathrm{M}|\mathrm{G}| 1 \mid \mathrm{K}$ queuing models is given in [13]. The elevator and shuttle vehicle cycle times are estimated by approximated expressions. The elevator SCC time multiply with number of tiers is estimated as the inter-arrival time. The service time is estimated as expected shuttle vehicle DCC time. By proposed approach racking geometry could be optimized maximizing in the same time the system throughput. The throughput capacities obtained by $\mathrm{M}|\mathrm{M}| 1 \mid \mathrm{K}$ model where the shuttle operates with DCC, $\mathrm{M}|\mathrm{G}| 1 \mid \mathrm{K}$ model where the shuttle operates with DCC, $\mathrm{M}|\mathrm{G}| 1 \mid \mathrm{K}$ model where the shuttle operates with SCC and by the simulation model for two racking lengths are compared. Small differences among model results are identified. Authors also brought idea that optimal racking geometry could be achieved using the linear optimization of the throughput expression from the applied queuing models. Optimal racking geometry for the two storage volumes using the proposed idea is presented.

Main AS/RS types, configurations and design and application specifics are given in [14]. Analytical model for tier-captive SBS/RS elevator lifting table and shuttle vehicle SCC and DCC times calculation based on elevator lifting table and shuttle vehicle movement probability distribution functions is presented. Acceleration and deceleration are considered through two elevator lifting table and shuttle vehicle velocity type profiles. Analytical model for the elevator lifting table and shuttle vehicle energy consumption estimation considering acceleration, deceleration and constant speed movement as well as the analytical model for the calculation of the energy regenerated during the braking of the elevator lifting table and shuttle vehicle are presented. Case study investigated throughput capacity, energy consumption and energy regeneration of SBS/RS with nine different racking configurations and five elevator and shuttle vehicles velocity profiles. As the elevator is usual bottleneck better utilization of the shuttle vehicles only could be achieved by releasing the assumption of tier-captive configuration. The biggest energy regeneration is recorded for the highest velocity profile emphasizing the necessity for the applying energy regeneration pattern in SBS/RS.

Analytical model for the tier-captive SBS/RS multiobjective optimization is presented [15]. Three objective functions are considered, cycle time, energy consumption and total system costs minimization. System decision variables are number of racking tiers, columns and aisles and elevator lifting tables and shuttle vehicle velocity type profiles. Costs structure consisting of elevators, shuttle vehicles and racking costs, storage area yearly investment cost and elevator lifting tables and shuttle vehicles yearly energy consumption. Genetic algorithm was used for the Pareto optimal solutions estimation. In the illustrative example some Pareto optimal solutions sorted by the throughput time, total cost and energy consumption are presented.

The tier-captive SBS/RS throughput estimation presented in [16] is based on modeling the one system tier by the $\mathrm{M}|\mathrm{G}| 1 \mid \mathrm{K}$ queueing model. Elevator SCC time approximation multiplied with number of tiers is used for determination of the inter-arrival time. The shuttle vehicle approximated DCC time is adopted as a service time. In the paper the model for the system energy consumption including the standby consumption and system control energy consumption is also presented. Expressions for energy consumption depending on a travelling direction for acceleration, deceleration and constant speed ride are developed. An example of the SBS/RS throughput and energy consumption calculations depending on the single deep racking height is presented. The curves that represent throughput and energy consumption are almost mirrored with some mismatching in picks positions due to the tote waiting time.

In the paper [17] one aisle of the single-deep tiercaptive SBS/RS is modeled as open queueing network. The elevator and shuttle vehicles represent different servers or nodes servicing storage and retrieval transactions. The service procedure depending on a transaction type has a different servicing sequence. Elevator is modeled by the $\mathrm{G} / \mathrm{G} / 2$ queueing system while the shuttle vehicles are modeled by $\mathrm{G} / \mathrm{G} / \mathrm{m}$ queueing system (where $\mathrm{m}$ is a number of shuttles in an aisle). Service time of nodes is described with mean value and squared coefficient of variation. Main network operations departure, superposition and split on arrival rates are also represented by mean value and squared coefficient of variation adopting Discrete Time Markov Chain modelling approach. The elevator queue mean transaction waiting time, mean number of transactions waiting in a elevator queue, and elevator and shuttle vehicles utilizations are chosen as system performance measures. Analytical results are validated thought simulation experiments. Proposed analytical approach could help in avoiding the potential bottlenecks during the SBS/RS initial design phase.

Paper [18] presented possibilities for the tier-captive SBS/RS throughput improvement by introducing management policies of class-based storage, warehouse reorganization and sequencing of retrieval transactions. In order to optimized system throughput the average elevator throughput per tier and shuttle vehicles throughput should be theoretically as close as possible. The throughput differences lead to the transaction waiting time increase. Three different zone configurations depending on applied elevator command cycle are investigated. Simple rule for the sequencing of the retrieval transactions minimizing the elevator DCC time is adopted. Warehouse reorganization consisting of three different processes is introduced. Systems performances are investigated by simulation 
experiments. Results indicated that class-based storage management policy managed to increase the throughput by making the elevator and shuttle vehicles waiting times as shortest as possible. Sequencing of retrieval transactions also increased the throughput by choosing the shortest travel time in elevator DCCs. Mutual application of class-based storage and sequencing of retrieval transactions further increased the throughput performance. Results proved that order executing time could be dramatically decreased by applying the warehouse reorganization management policy.

The system control strategies in tier-to-tier SBS/RS configuration are presented in [19]. The configuration allows lower number of batter utilized shuttles but also leads to operation difficulties such as collision and deadlock appearance. In order to achieve the minimal number of shuttle vehicles needed for the curtain number of tiers shuttle vehicles position control should be inbounded. Free balancing approach dynamically monitoring position of each shuttle vehicle and load (tote), preventing the traffic problems and balancing work load among shuttle vehicles could be a good solution. Simulation model for the investigation of the effects of applied approach is presented. First the storage transaction process logic (STPL) is described in which the control should choose which load from specific tier could call the shuttle vehicles and which shuttle vehicle should complete the task. In STPL three different load assignment policies (LAP) exist. Random policy in which storage transaction chooses the tier randomly and selects the closest available bay from the input point, shuttle vehicle priority policy where load should select the tier with already available shuttle vehicle or shuttle vehicle that is assigned to the tier by another load. But if selected tier does not have a sufficient number of bays the incoming load will choose the tier without available shuttle vehicles or shuttle vehicles designated by some other load. By following logic the system is dynamically controlled as the load storage positions are determined on the base of shuttle vehicles current locations. That logic allows the free balancing essence. In closest assignment policy load chooses the closes available bay to the first tier input point. Due to different described polities two retrieval transaction process logics (RTPL) are established: RTPL1 for the applied random assignment policy and RTPL2 when shuttle vehicles priority and closest assignment policies are applied. The main difference among them is retrieval transaction possibility to order the shuttle vehicles transfer between tiers. Depending on a described policies and logics three whole system controls are defined. The basic random control (BRC), consisting of a STPL, RTPL1 and random LAP, free balancing (FB) control, consisting of a STPL, RTPL2 and shuttle priority and closest control (CC), consisting of a STPL, RTPL2 and closest LAP. Using the simulation model the system performance measures, average and different categories of shuttle vehicle utilization, elevator utilization, average storage and retrieval cycle times of tier-captive SBS/RS with BRC and $\mathrm{CC}$ system controls are investigated. Results indicated the elevator as a potential bottleneck. Performance measures in tier-to-tier configuration for three different whole system controls are also compared. Results showed that system performances with applied BRC control are better than with CC control. Further FB control turned out to be more effective than BRC control especially in elevator cycle time and utilization performance measures. Also the FB control proved superiority over the two other whole system controls in terms of shuttle vehicle utilization balancing which assures also the shortest transaction cycle time.

The paper [20] presented the simulation model for the tier-captive SBS/RS performance estimation. Performance measures are average elevator lifting table and shuttle vehicle DCC times, corresponding elevator lifting table and shuttle vehicle throughput capacities and whole system throughput storage capacity. Elevator lifting table and shuttle vehicle movements are calculated according two types of velocity-time dependence. Author introduced the Design of Experiment (DOE), design technique able to investigate the influence of the input data on system performances based on significant parameters identification. The significant parameters are number of racking columns, shuttle vehicle and elevator lifting table velocity and acceleration/deceleration rates. The possible parameter levels are introduced together with minimum storage capacity and racking minimum and maximum height. Using DOE the best SBS/RS throughput performance could be obtained in the crossing area of the elevator lifting table and shuttle vehicle throughput capacities curves where both lifting table and shuttle vehicles operate with maximum utilization.

The simulation model for tier-captive SBS/RS throughput evaluation with applied class-based storage policy (CSP) is given in [21]. The totes are organized in $\mathrm{A}, \mathrm{B}$ and $\mathrm{C}$ classes and each class is located in predefined tiers. Class A totes are located in first tiers, i.e., in tiers with shortest distance from aisle input/output point and class $\mathrm{C}$ totes are located in farthest tiers (with longest distance from aisle input/output point). Class A totes with a possibility of $80 \%$ to be requested are located in $20 \%$ of tiers, class B totes with a possibility of $15 \%$ are located in $30 \%$ of all tiers, and class $\mathrm{C}$ totes with probability of $5 \%$ are located in rest of the tiers. In predefined tiers the totes with same class are located randomly. System performances are elevator utilization, shuttle vehicle utilization, average storage and retrieval cycle times. Results indicated that shuttles serving the class A totes usually become a bottleneck. The CSP gives the better results if system has a bigger number of tiers instead of lower configuration. Authors noted also that small number of aisles is more sensitive to blocking due to the fact that with such a configuration the aisle arrival rate is increased. Under storage capacity constraint the number of bays is high so shuttles serving the A class totes could not bear the transactions frequency. With a constant number of tiers the system performances increase when number of aisles increases (as number of bays decreases).

In the reference [22] the simulation model for tiercaptive SBS/RS average transaction cycle time and average energy consumption per transaction estimation is presented. Two velocity-time cases are applied. Last 
elevator lifting table and shuttle position is adopted as a well point. The elevator lifting table operates in SCC or DCC and random storage policy is adopted. Different racking configurations, elevator lifting table velocity profiles and transaction arrival rates are investigated. Results indicated that the elevator utilization decrease directly influence the increase of transaction energy consumption and decrease of average transaction cycle time, probably as the number of DC also decreases. The higher number of tier, as well as higher elevator lifting table velocities, leads to higher transaction energy consumption. For the constant elevator utilization number of bays increase results in average transaction cycle time and transaction energy consumption increases.

The tier-captive SBS/RS throughput calculation based on simulation model is showed in [23]. Elevator lifting tables and shuttle vehicles operate in SCC and DCC according to two velocity type profiles. Nine different racking layouts for just one velocity profile for elevator lifting table and shuttle vehicles are investigated. The model calculates cycle time and throughput of the elevator, shuttle vehicles and for the whole system. Results indicated the elevator as mainly system bottleneck so the efficiency of the system is strongly influences by number of racking columns and number of aisles. For the short racking with many aisles system performances are better comparing with other possible racking configurations. Presented simulation model could be a useful tool for the related decision makers in the early SBS/RS design phase.

One of recent literature review on the $\mathrm{SBS} / \mathrm{RS}$ is presented in [24].

The comparison of papers developed models, main assumptions, main approximations, and other related information are given in Table 1.

\section{CONCLUSION}

In the last decade SBS/RS have become preferable solution for the automated handling of totes spatially in the case of extremely high throughput demands. They also perform a considerable extension flexibility and high energy efficiency resulting from lower energy consumption and high energy regeneration capability. The models given into SBS/RS literature review could help SBS/RS designers and other related decision makers to estimate the system efficiency in the starting phase of SBS/RS design activities and assure proper operation of the system by preventing node point congestions or poor system utilization.

\section{ACKNOWLEDGMENT}

This work is a contribution to the Ministry of Education, Science and Technological Development of Republic of Serbia funded project TR 35006.

\section{REFERENCES}

[1] Marchet, G., Melacini, M., Perotti, S., Tappia, E.: Analytical model to estimate performances of autonomous vehicle storage and retrieval systems for product totes, International Journal of
Production Research (IJPR), Vol. 50, No. 24, pp. 7134-7148, 2012.

[2] Lerher, T., Rosi, B., Ekren, B.Y., Sari, Z.: A model for throughput performance calculations of shuttle based storage and retrieval systems, Tehnički vjesnik, Vol. 19, No. 4, pp. 709-715, 2012.

[3] Marchet, G., Melacini, M., Perotti, S., Tappia, E.: Development of a framework for the design of autonomous vehicle storage and retrieval systems, International Journal of Production Research (IJPR), Vol. 51, No. 14, pp. 4365-6387, 2013.

[4] Lerher, T.: Modern automation in warehousing by using the shuttle based technology, Automation Systems of the $21^{\text {st }}$ Century: New Technologies, Applications and Impacts on the Environment \& Industrial Processes, pp. 51-86, Nova Science Publishers, New York, 2013.

[5] Oser, J., Reisinger, K.: Cycle time and drive optimization of a high performance transfer car, in Progress in Material Handling Research, The Material Handling Industry of America, pp. 446-457, 2008.

[6] Sari, Z., Ghomri, L., Ekren, B.Y., Lerher, T.: Experimental validation of travel time models for shuttle-based automated storage and retrieval system, Proceedings of the International Material Handling Research Colloquium - 2014, 23-27 June 2014, Cincinnati, Ohio, USA, Vol. 1, pp. 1-20, 2014.

[7] Kartnig, G., Oster, J.: Throughput analysis of S/R shuttle systems, Proceedings of the International Material Handling Research Colloquium - 2014, 23-27 June 2014, Cincinnati, Ohio, USA, Vol. 1, pp. 1-20, 2014.

[8] Lerher, T., Ekren, B.Y., Đukic, G., Rosi, B.: Travel time model for shuttle-based storage and retrieval systems, The International Journal of Advanced Manufacturing Technology, Vol. 78, No. 9-12, pp. 1705-1725, 2015.

[9] Lerher, T., Ekren, B.Y., Sari, Z., Rosi, B.: Simulation analysis of shuttle based storage and retrieval systems, International Journal of Simulation Modelling, Vol. 17, No. 1, pp. 48-59, 2015.

[10]Eder, M., Kartnig, G.: Throughput analysis of S/R shuttle systems and ideal geometry for high performance, FME Transactions, Vol. 44, No. 2, pp. 174-179, 2016.

[11]Lerher, T.: Travel time model for double-deep shuttle-based storage and retrieval systems, International Journal of Production Research (IJPR), Vol. 54, No. 9, pp. 2519-2540, 2016.

[12] Kalyanaraman, P., Keerthika, C.: A review on automated storage/retrieval systems and shuttle based storage/retrieval systems, International Journal on Recent and Innovation Trends in Computing and Communication, Vol.4, No. 11, pp. 167-171, 2016.

[13]Eder, M.; Karting, G.: Throughput optimization of shuttle system with an analytical calculation model, 
In: Logistics Journal: Proceedings 2016, DOI 10.2195/1j_Proc_eder_de_201610_01., 2016.

[14]Lerher, T.: Throughput and energy related performance calculations for shuttle based storage and retrieval systems, Nova Science Publishers Inc., New York, 2016.

[15] Borovinšek, M., Ekren, Y.B., Burinskiene, A., Lerher, T.: Multi-objective optimisation model of shuttle-based storage and retrieval system, Transport, Vol. 32, No. 2, pp. 120-137, 2017.

[16]Eder M., Kartnig G.: Calculation Method to Determine the Throughput and the Energy Consumption of $\mathrm{S} / \mathrm{R}$ Shuttle Systems, XXII International Conference on "Material Handling, Constructions and Logistics" - MHCL 2017, University of Belgrade, Faculty of Mechanical Engineering, pp. 201 - 206, ISBN 978-86-7083949-6, Belgrade, Serbia, 4 - 6 October, 2017.

[17] Ekren, B. Y. et al.: A Queuing Network Approach for Performance Estimation of Shuttle Based Storage and Retrieval System Design, XXII International Conference on "Material Handling, Constructions and Logistics" - MHCL 2017, University of Belgrade, Faculty of Mechanical Engineering, pp. 185 - 188, ISBN 978-86-7083949-6, Belgrade, Serbia, 4 - 6 October, 2017.

[18] Kriehn, T. et al., Fittinghoff M.: Storage management policies for the throughput optimization of shuttle-based storage and retrieval systems, XXII International Conference on "Material Handling, Constructions and Logistics" - MHCL 2017, University of Belgrade, Faculty of Mechanical Engineering, pp. 177 - 184, ISBN 978-86-7083949-6, Belgrade, Serbia, 4 - 6 October, 2017.

[19] Yunsoo Ha, Junjae Chae: Free balancing for a shuttle-based storage and retrieval system, Simulation Modelling Practice and Theory, Vol. 82, pp. 12-31, https://doi.org/10.1016/j.simpat.2017. 12.006ISSN: 1569-190X, Elsevier B.V., 2018.

[20]Lerher T.: Design of Experiments for Identifying the Throughput Performance of Shuttle-Based Storage and Retrieval Systems, 10th International Scientific Conference Transbaltica 2017, Transportation Science and Technology, Procedia Engineering 187, pp. 324-334, 2017.

[21]Ekren, B.Y., Sari, Z., Lerher, T.: Warehouse Design under Class-Based Storage Policy of Shuttle-Based Storage and Retrieval System, IFACPapersOnLine 48-3, pp. 1152-1154, 0.1016/j. ifacol.2015.06.239, 2015.
[22] Lerher, T.et al.: Simulation-based energy and cycle time analysis of shuttle-based storage and retrieval system, 14th International Material Handling Research Colloquium (IMHRC 2016), Karlsruhe Institute of Technology, pp. 1-13, BadenWürttemberg, Germany. 12-16 June, 2016.

[23]Lerher, T., Ekren, B.Y., Sari, Z., Rosi, B.: Method for evaluating the throughput performance of shuttle based storage and retrieval systems, Tehnički vjesnik, Vol. 23, No. 3, pp. 715-723, 2016.

[24] Kosanić, N., Milojević, G., Zrnić, N.: A Review on Shuttle Based Storage and Retrieval Systems, XXII International Conference on "Material Handling, Constructions and Logistics" - MHCL 2017, University of Belgrade, Faculty of Mechanical Engineering, pp. 211-218, ISBN 978-86-7083-9496, Belgrade, Serbia, 4 - 6 October, 2017.

\section{NOMENCLATURE}

SCC Single command cycles

DCC Dual command cycles

\section{ПРЕГЛЕД ЛИТЕРАТУРЕ ИЗ \\ ОБЛАСТИ СКЛАДИШНИХ СИСТЕМА БАЗИРАНИХ НА ШАТЛ ТЕХНОЛОГИЈИ}

\section{Н. Косанић, Г. Милојевић, Н. Зрнић}

Претходна деценија донела је прави процват у области аутоматских складишних система (SBS/RS) базираних на шатл технологији у многим индустријама. Њихова супериорност у односу на „mini-load“ аутоматске складишне системе огледа се првенствено у могућности већег протока складишних јединица кроз систем, великој флексибилности проширења система и много бољој енергетској ефикасности, која је резултат мање потрошње енергије и способности регенерације велике количине енергије.

Свеобухватан преглед литературе SBS/RS приказан у овом раду указује на главне специфичности, кључне претпоставке и апроксимације у развијеним моделима за процену вредности перформанси система или стратегијама за управљање системом, и истиче најважније закључке изведене из добијених резултата. Представљени приступи у моделирању система могу бити користан алат за пројектанте SBS/RS приликом процене ефикасности система у почетној фази пројектовања. 
Table 1. - The comparison of references developed models, main assumptions, main approximations and other related information

\begin{tabular}{|c|c|c|c|c|c|c|}
\hline No. & Authors & Developed model & $\begin{array}{c}\text { System } \\
\text { configuration }\end{array}$ & Main assumptions & Main approximations & $\begin{array}{l}\text { Considered } \\
\text { cycle type } \\
\text { (analytical } \\
\text { model results } \\
\text { are validated } \\
\text { through } \\
\text { simulation) } \\
\end{array}$ \\
\hline 1. & $\begin{array}{l}\text { Marchet, } \\
\text { G., } \\
\text { Melacini, } \\
\text { M., } \\
\text { Perotti, S. } \\
\text { Tappia, E. }\end{array}$ & $\begin{array}{l}\text { The analytical model for the tier- } \\
\text { captive SBS/RS transaction cycle } \\
\text { time estimation including transaction } \\
\text { waiting time. Transaction waiting } \\
\text { time estimation based on M/G/1 } \\
\text { open queuing network (using } \\
\text { decomposition approach). }\end{array}$ & Tier-captive & $\begin{array}{l}\text { Acceleration and } \\
\text { deceleration are } \\
\text { included into model } \\
\text { calculations. }\end{array}$ & $\begin{array}{l}\text { Component of the cycle time } \\
\text { related to the lift and shuttle vehicle } \\
\text { movement is obtained as a } \\
\text { weighted average of all possible } \\
\text { movements. }\end{array}$ & $\begin{array}{l}\mathrm{SCC}-\text { just } \\
\text { retrieval } \\
\text { transaction is } \\
\text { considered } \\
\text { (yes) }\end{array}$ \\
\hline 2. & $\begin{array}{l}\text { Lerher, T., } \\
\text { Rosi, B., } \\
\text { Ekren, B. } \\
\text { Y., Sari, Z. }\end{array}$ & $\begin{array}{l}\text { Simulation model for SBS/RS } \\
\text { elevator lifting table and shuttle } \\
\text { vehicle cycle time evaluation and } \\
\text { resulting system throughput } \\
\text { performance calculation. }\end{array}$ & Tier-captive & $\begin{array}{l}\text { Acceleration and } \\
\text { deceleration are } \\
\text { considered through two } \\
\text { elevator lifting table } \\
\text { and shuttle vehicle } \\
\text { velocity type profiles. } \\
\end{array}$ & No & $\begin{array}{c}\text { SCC and DCC } \\
\text { (yes) }\end{array}$ \\
\hline 3. & $\begin{array}{l}\text { Marchet, } \\
\text { G., } \\
\text { Melacini, } \\
\text { M., } \\
\text { Perotti, S., } \\
\text { Tappia, E. }\end{array}$ & $\begin{array}{l}\text { Simulation model for the estimation } \\
\text { of the influence of main design } \\
\text { variables onto SBS/RS costs and } \\
\text { performance measures. }\end{array}$ & Tier-captive & $\begin{array}{l}\text { Acceleration and } \\
\text { deceleration are took } \\
\text { into consideration as a } \\
\text { fix time component. }\end{array}$ & $\begin{array}{l}\text { Simplified estimation of the } \\
\text { elevator and vehicle expected cycle } \\
\text { times by assuming average travel } \\
\text { distance as half of the maximal } \\
\text { travel distance. }\end{array}$ & $\begin{array}{l}\mathrm{SCC}-\text { just } \\
\text { retrieval } \\
\text { transaction is } \\
\text { considered } \\
\text { (yes) }\end{array}$ \\
\hline 4. & Lerher, $\mathrm{T}$. & $\begin{array}{l}\text { Analytical approximated model for } \\
\text { the SBS/RS elevator lifting table and } \\
\text { shuttle vehicle cycle times } \\
\text { estimation. Analytical model for } \\
\text { estimation of the energy } \\
\text { regeneration during braking of the } \\
\text { shuttle vehicle and elevator lifting } \\
\text { tables and corresponding mass of } \\
\text { saved } \mathrm{CO}_{2} \text { emission. Equivalent } \\
\text { amount of forest saved by the energy } \\
\text { regeneration also could be estimated. }\end{array}$ & Tier-captive & $\begin{array}{l}\text { Acceleration and } \\
\text { deceleration are } \\
\text { considered through two } \\
\text { elevator lifting table } \\
\text { and shuttle vehicle } \\
\text { velocity type profiles. } \\
\text { Number of energy } \\
\text { regenerations during } \\
\text { braking is adopted. }\end{array}$ & $\begin{array}{l}\text { Proposed model is based on the } \\
\text { probability theory and FEM } \\
\text { guidelines. }\end{array}$ & $\begin{array}{c}\text { SCC and DCC } \\
\text { (no) }\end{array}$ \\
\hline 6. & $\begin{array}{l}\text { Sari, Z., } \\
\text { Ghomri, L., } \\
\text { Ekren, B. } \\
\text { Y., Lerher, } \\
\text { T. }\end{array}$ & $\begin{array}{l}\text { Analytical approximated model for } \\
\text { the SBS/RS elevator lifting table and } \\
\text { shuttle vehicle travel time estimation } \\
\text { depending on four acceleration and } \\
\text { deceleration rates. }\end{array}$ & Tier-captive & $\begin{array}{l}\text { Acceleration and } \\
\text { deceleration are } \\
\text { included into model } \\
\text { calculations. }\end{array}$ & $\begin{array}{l}\text { Average travel time is calculated as } \\
\text { weighing average of all possible } \\
\text { times. Some smaller number of } \\
\text { summations is approximated. }\end{array}$ & $\begin{array}{c}\text { SCC and DCC } \\
\text { (yes) }\end{array}$ \\
\hline 7. & $\begin{array}{l}\text { Kartnig, G. } \\
\text { Oster, J. }\end{array}$ & $\begin{array}{l}\text { Analytical model for the SBS/RS } \\
\text { throughput estimation based on } \\
\text { modeling an aisle by } \mathrm{M}|\mathrm{G}| 1 \mid \text { queuing } \\
\text { model. }\end{array}$ & Tier-captive & $\begin{array}{l}\text { Acceleration and } \\
\text { deceleration are } \\
\text { included into model } \\
\text { calculations. }\end{array}$ & $\begin{array}{l}\text { The elevator and shuttle vehicle } \\
\text { cycle times are approximated. } \\
\text { Expected cycle times are } \\
\text { approximated. Storage transactions } \\
\text { inter-arrival time is estimated as } \\
\text { approximated expected elevator } \\
\text { SCC time. Retrieval transactions } \\
\text { inter-arrival time is estimated as } \\
\text { approximated expected shuttle } \\
\text { vehicle DCC time divided with a } \\
\text { number of tiers. }\end{array}$ & SCC (yes) \\
\hline 8. & $\begin{array}{l}\text { Lerher, T., } \\
\text { Ekren, B. } \\
\text { Y., } \\
\text { Đukić, G., } \\
\text { Rosi, B. }\end{array}$ & $\begin{array}{l}\text { Analytical model for SBS/RS } \\
\text { elevator lifting table and shuttle } \\
\text { vehicle cycle time calculation based } \\
\text { on lifting and traveling probability } \\
\text { distribution functions. Approximated } \\
\text { analytical model for elevator lifting } \\
\text { table and shuttle vehicle cycle time } \\
\text { estimation. }\end{array}$ & Tier-captive. & $\begin{array}{l}\text { Acceleration and } \\
\text { deceleration are } \\
\text { considered through two } \\
\text { lift and shuttle vehicle } \\
\text { velocity type profiles. }\end{array}$ & $\begin{array}{l}\text { Approximated analytical model is } \\
\text { based on the probability theory and } \\
\text { FEM guidelines. }\end{array}$ & $\begin{array}{c}\text { SCC and DCC } \\
\text { (yes) }\end{array}$ \\
\hline 9. & $\begin{array}{l}\text { Lerher, T., } \\
\text { Ekren, B. } \\
\text { Y., } \\
\text { Sari, Z., } \\
\text { Rosi, B. }\end{array}$ & $\begin{array}{l}\text { Simulation model for SBS/RS } \\
\text { performances estimation through } \\
\text { elevator lifting table and shuttle } \\
\text { vehicle cycle time calculation. }\end{array}$ & Tier-captive & $\begin{array}{l}\text { Acceleration and } \\
\text { deceleration are } \\
\text { considered through two } \\
\text { elevator lifting table } \\
\text { and shuttle vehicle } \\
\text { velocity type profiles. } \\
\end{array}$ & No. & DCC (yes) \\
\hline
\end{tabular}


Table 1. - The comparison of references developed models, main assumptions, main approximations and other related information [continued]

\begin{tabular}{|c|c|c|c|c|c|c|}
\hline No. & Authors & Developed model & $\begin{array}{c}\text { System } \\
\text { configuration }\end{array}$ & Main assumptions & Main approximation & $\begin{array}{c}\text { Considered } \\
\text { cycle type } \\
\text { (analytical } \\
\text { model } \\
\text { results are } \\
\text { validated } \\
\text { through } \\
\text { simulation) }\end{array}$ \\
\hline 10. & $\begin{array}{l}\text { Eder, M., } \\
\text { Kartnig, G. }\end{array}$ & $\begin{array}{l}\text { Analytical model for the SBS/RS } \\
\text { throughput estimation based on elevator } \\
\text { and shuttle vehicle velocity profiles, } \\
\text { racking geometry and transaction arrival } \\
\text { rates. One tier is modelled by an open } \\
\mathrm{M} / \mathrm{M} / 1 / \mathrm{K} \text { queuing model. By proposed } \\
\text { approach racking geometry could be } \\
\text { optimized maximizing in the same time the } \\
\text { system throughput. }\end{array}$ & Tier-captive & $\begin{array}{l}\text { Acceleration and } \\
\text { deceleration are } \\
\text { included into model } \\
\text { calculations. }\end{array}$ & \begin{tabular}{|l|} 
Expected cycle times are \\
approximated. The inter- \\
arrival time is estimated as \\
approximated expected \\
elevator SCC time multiply \\
with number of tiers. The \\
service time is estimated as \\
expected SCC or DCC \\
shuttle vehicle cycle times. \\
\end{tabular} & $\begin{array}{c}\text { SCC and } \\
\text { DCC (yes) }\end{array}$ \\
\hline 11. & Lerher, T. & $\begin{array}{l}\text { Analytical model for the double-deep } \\
\text { SBS/RS throughput performance } \\
\text { estimation. Depending on storage fill-grade } \\
\text { factor using the probability theory elevator } \\
\text { lifting table and shuttle vehicle SCC and } \\
\text { DCC time expressions are derived. }\end{array}$ & Tier-captive & $\begin{array}{l}\text { Acceleration and } \\
\text { deceleration are } \\
\text { considered through two } \\
\text { elevator lifting table } \\
\text { and shuttle vehicle } \\
\text { velocity type profiles. } \\
\text { The cycle time } \\
\text { calculations take into } \\
\text { consideration blocking } \\
\text { unit rearrangement } \\
\text { which occurs during } \\
\text { the retrieval process. } \\
\end{array}$ & No. & $\begin{array}{c}\text { SCC and } \\
\text { DCC (yes) }\end{array}$ \\
\hline 13. & $\begin{array}{l}\text { Eder, M., } \\
\text { Kartnig, G. }\end{array}$ & $\begin{array}{l}\text { Analytical approach for the SBS/RS } \\
\text { throughput estimation based on elevator } \\
\text { and shuttle vehicle velocity profiles, } \\
\text { racking geometry and transaction arrival } \\
\text { rates. One tier is modeled by } \mathrm{M}|\mathrm{M}| 1 \mid \mathrm{K} \text { and } \\
\mathrm{M}|\mathrm{G}| 1 \mid \mathrm{K} \text { queuing models. By proposed } \\
\text { approach racking geometry could be } \\
\text { optimized maximizing in the same time the } \\
\text { system throughput. }\end{array}$ & Tier-captive & $\begin{array}{l}\text { Acceleration and } \\
\text { deceleration are } \\
\text { included into model } \\
\text { calculations. }\end{array}$ & $\begin{array}{l}\text { Expected elevator SCC and } \\
\text { shuttle vehicle DCC times } \\
\text { are approximated. The } \\
\text { inter-arrival time is } \\
\text { estimated as approximated } \\
\text { expected lift SCC time } \\
\text { multiply with number of } \\
\text { tiers. The service time is } \\
\text { estimated as expected SCC } \\
\text { or DCC shuttle vehicle } \\
\text { cycle times. }\end{array}$ & $\begin{array}{c}\text { SCC and } \\
\text { DCC (yes) }\end{array}$ \\
\hline 14. & Lerher, $\mathrm{T}$. & $\begin{array}{l}\text { Analytical model for SBS/RS elevator } \\
\text { lifting table and shuttle vehicle cycle time } \\
\text { calculation based on lifting and traveling } \\
\text { probability distribution functions. } \\
\text { Approximated analytical elevator lifting } \\
\text { table and shuttle vehicle cycle time model. } \\
\text { Analytical model for the elevator lifting } \\
\text { table and shuttle vehicle energy } \\
\text { consumption estimation. Analytical model } \\
\text { for the energy regeneration estimation. }\end{array}$ & Tier-captive & $\begin{array}{l}\text { Acceleration and } \\
\text { deceleration are } \\
\text { considered through two } \\
\text { elevator lifting table } \\
\text { and shuttle vehicle } \\
\text { velocity type profiles. } \\
\text { Number of energy } \\
\text { regenerations during } \\
\text { braking is adopted. }\end{array}$ & $\begin{array}{l}\text { Approximated expression } \\
\text { for the elevator lifting table } \\
\text { and shuttle vehicle constant } \\
\text { speed movement distances } \\
\text { into the energy } \\
\text { consumption model. }\end{array}$ & $\begin{array}{l}\text { SCC and } \\
\text { DCC (no) }\end{array}$ \\
\hline 15 . & $\begin{array}{l}\text { Borovinšek, } \\
\text { M., Ekren, Y. } \\
\text { B., } \\
\text { Burinskiene, } \\
\text { A., Lerher, T. }\end{array}$ & $\begin{array}{l}\text { Analytical model for the SBS/RS multi } \\
\text { objective optimization consisting of three } \\
\text { objective functions: minimization of cycle } \\
\text { time, energy consumption and total system } \\
\text { costs. }\end{array}$ & Tier-captive & $\begin{array}{l}\text { Acceleration and } \\
\text { deceleration are } \\
\text { included into model } \\
\text { calculations. }\end{array}$ & $\begin{array}{l}\text { Expected elevator lifting } \\
\text { table and shuttle vehicle } \\
\text { SCC and DCC times are } \\
\text { approximated. } \\
\text { Approximated expression } \\
\text { for the elevator lifting table } \\
\text { and shuttle vehicle constant } \\
\text { speed movement distances } \\
\text { into the energy } \\
\text { consumption model. }\end{array}$ & $\begin{array}{l}\text { SCC and } \\
\text { DCC (no) }\end{array}$ \\
\hline 16. & $\begin{array}{l}\text { Eder, M.., } \\
\text { Kartnig, G. }\end{array}$ & $\begin{array}{l}\text { Analytical model for the SBS/RS } \\
\text { throughput estimation based on modeling } \\
\text { the one system tier by the } \mathrm{M}|\mathrm{G}| 1 \mid \mathrm{K} \\
\text { queueing model. Energy consumption } \\
\text { model including the standby consumption } \\
\text { and system control energy consumption. }\end{array}$ & Tier-captive & $\begin{array}{l}\text { Acceleration and } \\
\text { deceleration are } \\
\text { included into model } \\
\text { calculations. }\end{array}$ & $\begin{array}{l}\text { Expected elevator and } \\
\text { shuttle vehicle cycle times } \\
\text { are approximated. The } \\
\text { inter-arrival time is } \\
\text { estimated as approximated } \\
\text { expected elevator SCC } \\
\text { time multiply with number } \\
\text { of tiers. The service time is } \\
\text { estimated as expected SCC } \\
\text { and DCC shuttle vehicle } \\
\text { cycle times. }\end{array}$ & $\begin{array}{l}\text { SCC and } \\
\text { DCC (no) }\end{array}$ \\
\hline
\end{tabular}


Table 1. - The comparison of references developed models, main assumptions, main approximations and other related information [continued]

\begin{tabular}{|c|c|c|c|c|c|c|}
\hline No. & Authors & Developed model & $\begin{array}{c}\text { System } \\
\text { configuration }\end{array}$ & Main assumptions & Main approximation & $\begin{array}{l}\text { Considered } \\
\text { cycle type } \\
\text { (analytical } \\
\text { model } \\
\text { results are } \\
\text { validated } \\
\text { through } \\
\text { simulation) } \\
\end{array}$ \\
\hline 17. & $\begin{array}{l}\text { Ekren, B. Y., } \\
\text { Akpunar, A., } \\
\text { Sari, Z., Lerher, } \\
\text { T. }\end{array}$ & $\begin{array}{l}\text { Analytical model for the SBS/RS main system } \\
\text { performances estimation by modeling the tier as } \\
\text { an open queueing network }(\mathrm{G} / \mathrm{G} / \mathrm{m}) \text { using } \\
\text { decomposition method. The elevator queue } \\
\text { mean transaction waiting time, mean number of } \\
\text { transactions waiting in elevator queue, and } \\
\text { elevator and shuttle vehicle utilizations are } \\
\text { chosen as system performance measures. }\end{array}$ & Tier-captive & $\begin{array}{l}\text { Acceleration and } \\
\text { deceleration are included } \\
\text { into model calculations }\end{array}$ & No & $\begin{array}{c}\text { SCC and } \\
\text { DCC (yes) }\end{array}$ \\
\hline 18. & $\begin{array}{l}\text { Kriehn, T., } \\
\text { Schloz F., } \\
\text { Wehking K., H., } \\
\text { Fittinghoff M. }\end{array}$ & $\begin{array}{l}\text { Simulation model for the SBS/RS throughput } \\
\text { estimation taking into consideration the different } \\
\text { management policies of class-based storage, } \\
\text { warehouse reorganization and sequencing of } \\
\text { retrieval transactions. }\end{array}$ & Tier-captive & $\begin{array}{l}\text { Acceleration and } \\
\text { deceleration are included } \\
\text { into model calculations. }\end{array}$ & No & $\begin{array}{c}\text { SCC and } \\
\text { DCC (yes) }\end{array}$ \\
\hline 19. & $\begin{array}{l}\text { Yunsoo Ha, } \\
\text { Junjae Chae }\end{array}$ & $\begin{array}{l}\text { Simulation model for the SBS/RS performance } \\
\text { measures estimation depending on three } \\
\text { different system control strategies. }\end{array}$ & Tier-to-tier & $\begin{array}{l}\text { Acceleration and } \\
\text { deceleration are included } \\
\text { into model calculations. } \\
\end{array}$ & No & SCC (yes) \\
\hline 20. & Lerher T. & $\begin{array}{l}\text { Simulation model for the tier-captive SBS/RS } \\
\text { performance estimation. Author introduced the } \\
\text { Design of Experiment (DOE), design technique } \\
\text { able to investigate the influence of the input data } \\
\text { on system performances based on significant } \\
\text { parameters identification. }\end{array}$ & Tier-captive & \begin{tabular}{|l|} 
Acceleration and \\
deceleration are \\
considered through two \\
elevator lifting table and \\
shuttle vehicle velocity \\
type profiles.
\end{tabular} & No & DCC (yes) \\
\hline 21. & $\begin{array}{l}\text { Ekren, B.Y., } \\
\text { Sari, Z., Lerher, } \\
\text { T. }\end{array}$ & $\begin{array}{l}\text { The simulation model for tier-captive SBS/RS } \\
\text { throughput evaluation with applied classes- } \\
\text { based storage policy. }\end{array}$ & Tier-captive & \begin{tabular}{|l|} 
Acceleration and \\
deceleration are \\
considered through two \\
elevator lifting table and \\
shuttle vehicle velocity \\
type profiles.
\end{tabular} & No & DCC (yes) \\
\hline 22. & $\begin{array}{l}\text { Lerher, T., } \\
\text { Ekren, B.Y., } \\
\text { Akpunar, A. }\end{array}$ & $\begin{array}{l}\text { Simulation model for tier-captive SBS/RS } \\
\text { average transaction cycle time and average } \\
\text { energy consumption per transaction estimation. }\end{array}$ & Tier-captive & $\begin{array}{l}\text { Acceleration and } \\
\text { deceleration are } \\
\text { considered through two } \\
\text { elevator lifting table and } \\
\text { shuttle vehicle velocity } \\
\text { type profiles. }\end{array}$ & \begin{tabular}{|l|} 
The elevator lifting \\
table energy \\
consumption \\
difference depending \\
of traveling direction \\
is not taken into \\
consideration. \\
\end{tabular} & $\begin{array}{l}\text { DCC and } \\
\text { SCC (Yes) }\end{array}$ \\
\hline 23. & $\begin{array}{l}\text { Lerher, T., } \\
\text { Ekren, B.Y., } \\
\text { Sari, Z., Rosi, B. }\end{array}$ & $\begin{array}{l}\text { Simulation model for the tier-captive SBS/RS } \\
\text { throughput calculation. }\end{array}$ & Tier-captive & \begin{tabular}{|l|} 
Acceleration and \\
deceleration are \\
considered through two \\
elevator lifting table and \\
shuttle vehicle velocity \\
type profiles.
\end{tabular} & No & $\begin{array}{l}\text { DCC and } \\
\text { SCC (Yes) }\end{array}$ \\
\hline
\end{tabular}

